\section{PENDAMPINGAN PELAKSANAAN PROTOKOL KESEHATAN PADA MASA PANDEMI COVID-19 BAGI SEKOLAH SEPAKBOLA EMSYK, PAPUA}

\author{
Octolia Togibasa ${ }^{*}$, Siane Maria \\ Tampi², Pahala Tua Hutajulu²
}

\begin{abstract}
Abstrak
Pandemi Coronavirus Disease 2019 atau COVID-19 telah berdampak di seluruh bidang kehidupan, termasuk dunia olahraga. Di kalangan sepakbola amatir, telah banyak akademi dan sekolah sepakbola yang harus menghentikan aktivitasnya. Namun seiring dengan dikenalkannya gaya hidup normal baru, maka aktivitas sekolah sepakbola dapat dimulai kembali, dengan disertai ketaatan melaksanakan protokol kesehatan. Kegiatan pengabdian ini bertujuan untuk memberikan pendampingan pelaksanaan protokol kesehatan pada masa pandemik COVID-19 bagi sekolah sepakbola Emsyk, Papua. Program pendampingan menggunakan pendekatan simulasi fisika untuk penyebaran droplet, dan berdasarkan panduan FIFA, maka dibuat infografis protokol kesehatan untuk sekolah sepakbola. Kegiatan pengabdian dilakukan secara daring serta luring. Edukasi protokol kesehatan dilakukan dalam bentuk ceramah dan diskusi secara daring untuk memberikan pemahaman seluruh siswa sekolah sepakbola Emsyk. Pendampingan dilakukan untuk membantu dan memastikan sekolah sepakbola Emsyk taat dalam pelaksanaan protokol kesehatan. Hasil dari evaluasi kegiatan yang dilakukan adalah sekolah sepakbola Emsyk telah mampu melaksanakan protokol kesehatan olahraga amatir yang sesuai standar internasional.
\end{abstract}

Kata Kunci: Pandemi Covid-19; Protokol Kesehatan; Sekolah Sepakbola

$\begin{array}{lll}\text { Article history } & \\ \text { Received } & \text { 08-10-2020 } \\ \text { Revised } & \text { 04-02-2021 } \\ \text { Accepted }: & 15-03-2021\end{array}$

*Corresponding author Octolia Togibasa

Email: octolia@gmail.com

\begin{abstract}
The COVID-19 pandemic has affected all areas of life, including the world of sports. Football academy in the whole world has to suspend their activities. However, along with implementing a new normal, football academy activities can be restarted, along with the implementation of health protocols. This service activity aims to implement health protocols during the COVID-19 pandemic for Emsyk football school, Papua. The mentoring program uses a physics simulation approach for droplet dispersal, and based on FIFA guidelines, a health protocol infographic for football schools was created. Community service activities are carried out online and offline. Health protocol education is carried out in online lectures and discussions to provide understanding for all Emsyk football school students. Assistance is carried out to assist and ensure Emsyk football school adheres to the implementation of health protocols. The evaluation of the activities carried out was that the Emsyk football school was able to implement amateur sports health protocols according to international standards.
\end{abstract}

Keywords: COVID-19 Pandemic; Health Protocol; Football Academy

\section{PENDAHULUAN}

Sejak ditemukan di akhir tahun 2019, severe acute respiratory syndrome coronavirus 2 (SARS-CoV2), atau dikenal dengan virus corona, menyebar dengan cepat ke banyak negara di seluruh dunia. Hingga bulan September 2020, menurut data dari Worldometer, yaitu situs yang memberikan data statistik dunia pada waktu sebenarnya atau real time world statistic, tercatat lebih dari 29 juta kasus infeksi virus Corona (Worldometer, 2020). Pandemi ini akhirnya dikenal dengan Coronavirus Disease 2019 atau COVID-19. Berdasarkan penelitian medis, diketahui penyebaran virus jenis corona dapat terjadi secara efektif melalui media air liur, dalam bentuk mikro-tetesan atau micro-droplets (Wang et al., 2005; Xie et al., 2009). Praktik pencegahan tetesan atau droplet efektif untuk mengurangi risiko infeksi, karena infeksi ditularkan oleh tetesan batuk yang memiliki distribusi ukuran rata-rata sebesar 0,6215,9 um (Yang et al., 2007).

Pada saat seseorang bersin, batuk atau menghembuskan napas, orang tersebut memancarkan tetesan kecil yang tidak dapat dilihat dengan mata telanjang, yang bisa membawa virus. Orang lain dapat menerima infeksi dengan menghirup tetesan ini, atau dengan mendapatkan tetesan di 
tangan kemudian menyentuh wajah (Zhu et al. 2006). Itu sebabnya selama krisis pandemi COVID-19, banyak negara di seluruh dunia, termasuk Indonesia, telah menyatakan seruan pembatasan sosial dengan menjaga jarak sekitar 1-1,5 m antar individu (Abel \& McQueen, 2020). Hasil studi mengenai efektivitas pencegahan penularan kasus pernapasan atau severe acute respiratory syndrome (SARS) pada tahun 2003 memberikan empat rekomendasi tindakan pencegahan, yaitu: menggunakan masker, sarung tangan, gaun medis, dan mencuci tangan (Seto et al., 2003). Sesuai dengan hasil studi tersebut, pada masa pandemi COVID-19, organisasi kesehatan dunia WHO juga menyerukan prinsip $3 \mathrm{M}$ yaitu menggunakan masker, mencuci tangan, dan menjaga jarak (World Health Organization, 2020).

Pada tanggal 19 Maret 2020, Presiden Republik Indonesia Bapak Joko Widodo, melalui Kepala BNPB, menyampaikan hasil Rapat Terbatas (Ratas) secara daring, dimana salah satunya adalah: "Presiden meminta untuk tetap memperhatikan strategi dan kebijakan pemerintah pusat, yaitu social distancing yang meliputi jaga jarak, hindari kerumunan, di rumah saja dengan belajar, bekerja, dan juga beribadah" (Sekretaris Kabinet Republik Indonesia, 2020). Pada tanggal 31 Maret 2020, Presiden Republik Indonesia kemudian menetapkan Peraturan Pemerintah No 21 tahun 2020 tentang Pembatasan Sosial Berskala Besar dalam rangka Percepatan Penanganan Coronavirus Disease (COVID-19). Berdasarkan PP 21 Tahun 2020, Pasal 4, Pembatasan Sosial Berskala Besar paling sedikit meliputi: peliburan sekolah dan tempat kerja; pembatasan kegiatan keagamaan; dan/atau pembatasan kegiatan di tempat atau fasilitas umum.

Meskipun dalam masa pembatasan sosial, masyarakat tentu tetap diharapkan melakukan olahraga yang rutin, dalam rangka menjaga imunitas dan kesehatan tubuhnya (Pranata, 2020; Tiksnadi et al., 2020). Rangkaian penelitian di bidang Fisika Komputasi dan Teknik Fisika telah memberikan rekomendasi dalam jaga jarak saat berolahraga di luar ruangan dalam masa pembatasan sosial, untuk menghindari penularan virus antar individu. Dengan menggunakan pendekatan Fisika, khususnya bidang aerodinamika, ada beberapa faktor penting yang menjadi pembeda antara jaga jarak saat diam dan saat dinamis, misalnya saat berjalan, berlari, atau bersepeda. Faktor penting yang harus diperhatikan antara lain laju udara, kecepatan angin, serta konfigurasi antar individu saat berolahraga (Blocken et al., 2020)

Masalah menjadi lebih sulit ketika melibatkan olahraga tim, seperti sepakbola, bola basket, bola voli, dan lain-lain. Cabang olahraga sepakbola, sebagai cabang olahraga yang paling banyak diminati orang di seluruh dunia, mengalami dampak yang sangat signifikan. Seluruh kompetisi profesional, baik di tingkat elite maupun lokal harus ditunda, bahkan ada yang dihentikan. Di kalangan amatir, juga banyak akademi dan sekolah sepakbola harus menghentikan aktivitasnya. Seiring dengan dikenalkannya gaya hidup normal baru (new normal) maka organisasi olahraga dunia Fédération Internationale de Football Association (FIFA), menerbitkan buku panduan singkat memulai aktivitas sepakbola di era norma baru, dengan judul "COVID-19: Medical Considerations for a Return to Footballing Activity" (Fédération Internationale de Football Association, 2020).

Tiga kondisi penting panduan FIFA mengenai protokol kesehatan untuk sepakbola amatir, yaitu: saat kedatangan pemain ke dalam lingkungan lapangan sepakbola, saat latihan dalam tim sendiri, maupun saat uji coba atau pertandingan dan bertemu dengan tim lain. Setiap kondisi tersebut memiliki rekomendasi protokol kesehatan yang harus dilakukan. Meskipun penting, sayangnya hasil penelitian dan rekomendasi FIFA mengenai protokol kesehatan saat berolahraga masih berupa dokumen ilmiah sehingga menjadi sulit dimengerti bagi masyarakat umum. Diperlukan paket materi yang lebih sederhana disertai bimbingan teknis yang mudah dipahami, agar dapat diterapkan oleh masyarakat.

Sekolah Sepakbola (SSB) Emsyk merupakan salah satu SSB yang aktif di Kota Jayapura, Provinsi Papua, dengan memiliki siswa lebih dari 60 orang yang terbagi dalam tiga kelompok usia, senior, junior, dan anak-anak. Sejak akhir bulan Maret tahun 2020, SSB Emsyk menghentikan aktivitasnya dikarenakan pembatasan sosial di Kota Jayapura. Seiring dengan mulai diijinkannya kegiatan di luar ruangan sejak bulan Juni 2020 oleh Pemerintah Kota, SSB Emsyk berencana kembali melanjutkan aktivitas kegiatannya, khususnya untuk kelompok usia senior dan junior. Namun, muncul permasalahan yang dihadapi SSB Emsyk, yaitu belum adanya petunjuk teknis dari Persatuan Sepakbola Seluruh Indonesia (PSSI). Permasalahan tersebut disampaikan kepada tim pengabdian Universitas Cenderawasih, dengan harapan dapat membantu SSB Emsyk dalam melakukan aktivitasnya kembali, sesuai ketentuan pembatasan sosial.

Sekolah sepakbola, termasuk SSB Emsyk, merupakan kelompok masyarakat yang melakukan aktivitas olahraga dengan tetap memberikan perhatian penuh pada penerapan protokol kesehatan agar dapat terhindar dari paparan dan penyebaran virus Corona. Proses edukasi protokol kesehatan menjadi sangat penting dipahami dan dilakukan oleh SSB. Tujuan dari kegiatan ini adalah untuk memberikan edukasi protokol kesehatan 
sesuai standar FIFA kepada SSB Emsyk, agar dapat melakukan aktivitas olahraga di luar ruangan saat masa pandemik Covid-19.

\section{METODE PELAKSANAAN}

Metode kegiatan dilakukan dalam empat tahap kegiatan, dan dilakukan secara blended method (metode campur) yaitu secara daring dan luring.

1. Persiapan: Langkah ini dilakukan dalam bentuk survey ke tempat pelaksanaan kegiatan, mengatur jadwal, serta mempersiapkan materi serta perlengkapan protokol kesehatan yang diperlukan, sesuai dengan standard WHO sebagai badan kesehatan dunia, dan FIFA sebagai badan olahraga internasional. Persiapan dilakukan secara daring, selama 1 bulan sejak tanggal 5 hingga 26 Agustus 2020.

2. Edukasi: pada bagian ini, tim pengabdian memberikan edukasi mengenai protokol kesehatan dalam melakukan aktivitas sekolah sepak bola, melalui ceramah dan diskusi secara online. Sumber utama edukasi adalah simulasi pergerakan droplet saat berolahraga dengan pendekatan aerodinamika (Blocken et al., 2020), serta Standar Protokol Kesehatan Sepakbola bagi sepakbola amatir dari FIFA. Kegiatan edukasi dilakukan secara daring melalui aplikasi zoom, pada tanggal 5 September 2020.

3. Bimbingan dan Pendampingan: pada bagian ini tim pengabdian memberikan kontribusi perlengkapan protokol kesehatan, yaitu antara lain: media poster infografis, perlengkapan cuci tangan, dan thermometer gun. Selanjutnya selama kurang lebih tiga minggu, tim pengabdian melakukan pendampingan untuk memastikan komunitas SSB Emsyk telah melakukan protokol kesehatan dengan baik.

4. Evaluasi: Dilakukan formulir kendali (form control) untuk mengetahui tingkat ketaatan SSB Emsyk dalam melakukan protokol kesehatan, sebelum dan sesudah dilaksanakan kegiatan. Tahap bimbingan hingga evaluasi dilaksanakan pada tanggal 7-28 September 2020.

\section{PEMBAHASAN}

Dalam proses persiapan, tim pengabdian telah membuat materi serta perlengkapan protokol kesehatan yang diperlukan, sesuai dengan standar WHO dan FIFA. Untuk mempermudah proses edukasi kepada komunitas SSB, maka materi utama protokol kesehatan diringkas dan dibuat dalam media poster infografis (Gambar 1).

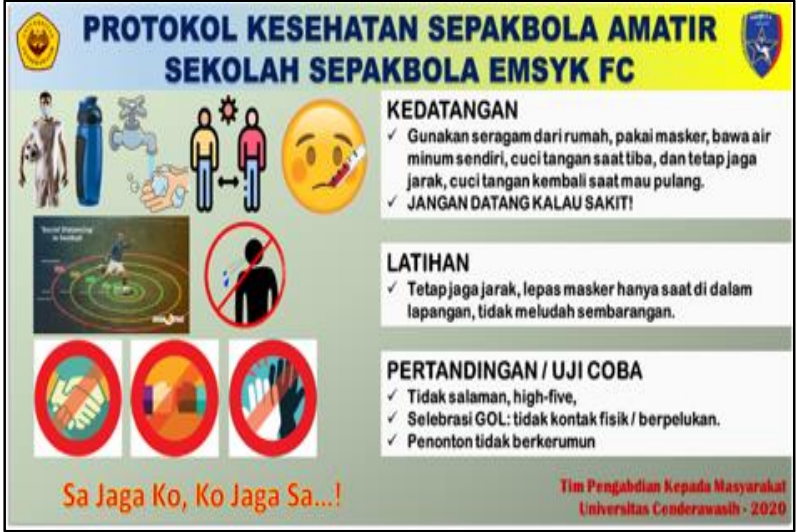

Gambar 1. Poster infografis protokol kesehatan sepakbola amatir SSB Emsyk

Program edukasi dilaksanakan dengan cara ceramah dan diskusi secara daring, dalam rangka memberikan edukasi protokol kesehatan kepada komunitas sasaran, siswa Sekolah Sepakbola Emsyk. Kegiatan dilaksanakan pada tanggal 5 September 2020, dan diikuti oleh 20 peserta (Gambar 2). Pertemuan dilakukan menggunakan aplikasi zoom. Kegiatan direkam dan diungah di media sosial youtube

(https://www.youtube.com/watch?v=9TaFlOgj0c0)

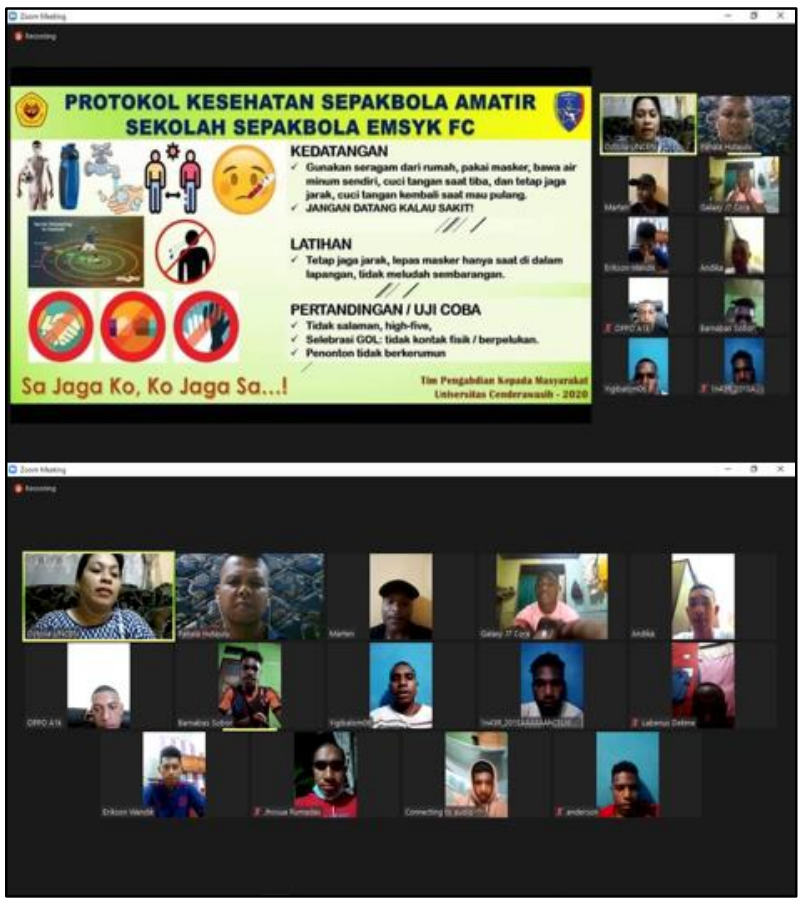

Gambar 2. Screen shoot kegiatan edukasi 
Hasil dari kegiatan edukasi ini adalah pemahaman yang baik dari siswa maupun pelatih/pengelola SSB Emsyk, mengenai apa saja yang harus dipersiapkan, dan dilaksanakan oleh SSB Emsyk dalam rangka melaksanakan protokol kesehatan. Sayangnya, karena keterbatasan jaringan, ada beberapa peserta yang tidak dapat mengikuti kegiatan zoom secara lengkap. Namun demikian mereka dapat menonton kembali melalui video kegiatan yang direkam dan diunggah di youtube.

Meskipun telah dilakukan edukasi melalui ceramah dan diskusi secara daring, namun pelaksanaan protokol kesehatan pandemi COVID-19 tidaklah mudah. Kpengabdian dilanjutkan dengan pendampingan sesuai dengan permintaan pengelola SSB Emsyk. Selama kurang lebih tiga minggu yaitu sejak 7 hingga 28 September 2020, tim pengabdi melakukan pendampingan dalam pelaksanaan protokol kesehatan. Hasil dari kegiatan ini, SSB Emsyk telah melaksanakan:

1. Pemasangan media infografis di tempat yang mudah dilihat, agar seluruh peserta komunitas dapat ingat dan terus patuh terhadap protokol kesehatan.

2. Penyediaan fasilitas cuci tangan dan thermometer gun.

3. Menerapkan protokol kesehatan dengan baik.

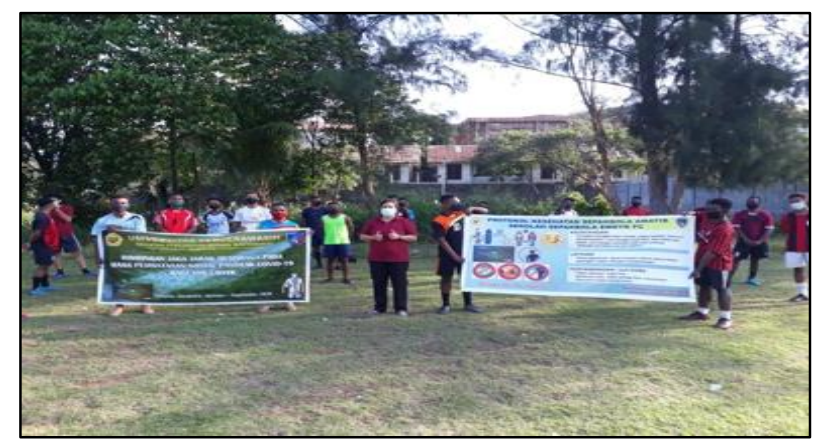

Gambar 3. Ketua tim (tengah) sedang memberikan materi edukasi di lokasi SSB Emsyk

Beberapa dokumentasi kegiatan pendampingan diberikan pada Gambar 3 dan Gambar 4. Gambar 3 memperlihatkan ketua tim pengabdian sedang memberikan materi edukasi, melalui media poster. Pemberian materi tetap memperhatikan protokol kesehatan yaitu memakai masker dan menjaga jarak. Pada Gambar 4 diberikan kumpulan foto contoh pelaksanakan protokol kesehatan di SSB Emsyk. Gambar 4(a) menunjukkan foto kedatangan siswa sudah menggunakan seragam, tidak lagi melakukan aktivitas ganti pakaian di lapangan. Siswa juga terlebih dahulu di cek suhu tubuhnya, dan dipastikan dalam keadaan sehat. Kegiatan pengecekan di saat kedatangan dilakukan oleh asisten pelatih SSB Emsyk. Setelah memasuki area SSB, siswa juga harus mencuci tangannya dengan sabun, yang tersedia di area pintu masuk SSB, seperti ditunjukkan pada gambar 4(b). Foto berikutnya pada gambar 4(c) menunjukkan siswa membawa botol minumannya sendiri, dan gambar 4(d) memberikan contoh bagaimana kegiatan pengarahan dari pelatih dilakukan dengan menjaga jarak dan memakai masker. Masker baru dibuka saat berada dalam lapangan.

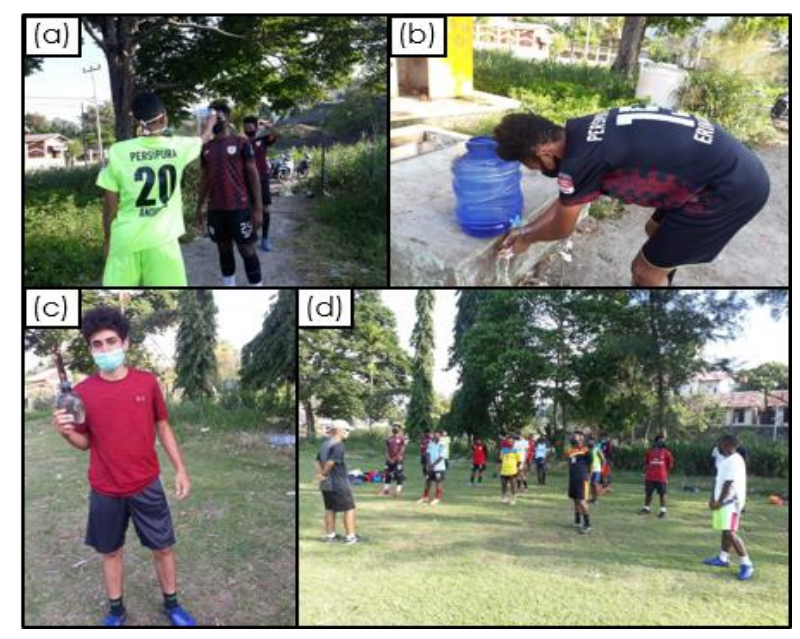

Gambar 4. Kumpulan foto contoh pelaksanaan protokol kesehatan di SSB Emsyk

Evaluasi program pengabdian dilakukan dalam bentuk check list formulir kendali, dan hasilnya dirangkum pada Tabel 1. Hasil evaluasi memberikan informasi bahwa SSB Emsyk sudah siap dan mampu melaksanakan protokol kesehatan sesuai standar WHO dan FIFA untuk sepakbola amatir. Terdapat 8 dari 11 item yang menunjukkan tingkat ketaatan $100 \%$, Terdapat 3 item yang belum mencapai tingkat ketaatan 100\%, yaitu: membawa botol minuman sendiri (90\%), tidak meludah sembarangan (80\%), dan penonton tidak berkerumun (80\%). Berdasarkan hasil evaluasi, tingkat ketaatan "membawa botol minuman sendiri" hanya mencapai 90\%, disebabkan faktor lalai. Seluruh siswa memiliki dan dapat membawa botol minuman, namun setiap latihan selalu masih ada siswa yang lalai, meskipun sudah diingatkan. Selanjutnya item "jangan membuang ludah sembarangan" hanya mencapai tingkat ketaatan sebesar 80\%, karena faktor sulitnya merubah kebiasaan, dimana membuang ludah sering dilakukan di luar kesadaran. Kelemahan lainnya terdapat pada item "Penonton tidak berkerumun", yang hanya mencapai tingkat ketaatan sebesar $80 \%$. Penonton masih lalai, disebabkan karena kegiatan ini masih berfokus pada komunitas siswa SSB, belum pada komunitas masyarakat umum, atau penonton. 
Tabel 1. Rangkuman hasil evaluasi pelaksanaan protokol kesehatan di SSB Emyk

\begin{tabular}{|c|c|c|c|}
\hline \multirow[t]{2}{*}{ Item Protokol Kesehatan } & \multicolumn{2}{|c|}{ Tingkat Ketaatan } & \multirow[t]{2}{*}{ Keterangan } \\
\hline & Sebelum & Sesudah & \\
\hline \multicolumn{4}{|l|}{ Saat Kedatangan } \\
\hline Penggunaan masker & $90 \%$ & $100 \%$ & Dilakukan dengan baik \\
\hline Membawa botol minuman sendiri & $70 \%$ & $90 \%$ & $\begin{array}{l}\text { Sudah meningkat kesadaran membawa } \\
\text { botol minuman sendiri, namun masih ada } \\
\text { yang lupa/lalai. }\end{array}$ \\
\hline Mencuci tangan & $50 \%$ & $100 \%$ & $\begin{array}{l}\text { Fasilitas cuci tangan disediakan } \\
\text { manajemen }\end{array}$ \\
\hline Tetap jaga jarak & $90 \%$ & $100 \%$ & Dilakukan dengan baik \\
\hline Jangan Datang Kalau Sakit & $100 \%$ & $100 \%$ & Dilakukan dengan baik \\
\hline \multicolumn{4}{|l|}{ Saat Latihan } \\
\hline Tetap jaga jarak & $90 \%$ & $100 \%$ & Dilakukan dengan baik \\
\hline Penggunaan masker & $90 \%$ & $100 \%$ & $\begin{array}{l}\text { Setelah kegiatan siswa SSB selalu } \\
\text { menggunakan masker selama di luar } \\
\text { lapangan, termasuk saat briefing dan di } \\
\text { bangku cadangan. }\end{array}$ \\
\hline Jangan Meludah Sembarangan & $30 \%$ & $80 \%$ & $\begin{array}{l}\text { Setelah kegiatan, mulai rutin dilakukan, } \\
\text { namun masih sulit merubah kebiasaan. }\end{array}$ \\
\hline \multicolumn{4}{|l|}{ Saat Pertandingan Uji Coba } \\
\hline Tidak melakukan high five & $90 \%$ & $100 \%$ & Dilakukan dengan baik \\
\hline Selebrasi gol tanpa kontak fisik & $90 \%$ & $100 \%$ & Dilakukan dengan baik \\
\hline Penonton tidak berkerumun & $60 \%$ & $80 \%$ & $\begin{array}{l}\text { Sulit dilakukan karena sasaran kegiatan } \\
\text { belum mencapai masyarakat umum } \\
\text { (penonton). }\end{array}$ \\
\hline
\end{tabular}

Secara keseluruhan dinilai proses edukasi dan pendampingan pelaksanaan protokol kesehatan dalam berolahraga dapat diterima baik oleh komunitas SSB Emsyk, dan SSB lain yang ada di Kota Jayapura. Sebelumnya, tim pengabdian juga telah melakukan kegiatan pengembangan aplikasi sains dalam sepakbola yang melibatkan SSB pada tahun 2018 dan 2019 (Hutajulu \& Togibasa, 2019; Togibasa \& Hutajulu, 2019). Meskipun mitra kegiatan hanya melibatkan satu SSB, namun melalui komunikasi antar komunitas, aplikasi kegiatan pengabdian dapat tersampaikan juga ke SSB lain yang ada di Kota Jayapura. Demikian juga pada kegiatan ini. Meski hanya dilakukan dengan 1 mitra, yaitu SSB Emsyk, namun mengingat tingkat komunikasi antar SSB yang sangat baik di Kota Jayapura, maka diharapkan informasi ini dapat diterima juga oleh SSB lain yang ada di Jayapura. Dengan demikian kesadaran melakukan protokol kesehatan dapat berdampak secara luas.

\section{KESIMPULAN}

Kegiatan pendampingan pelaksanaan protokol kesehatan pada masa pembatasan sosial pandemi Covid-19 telah dilakukan bagi mitra kegiatan Sekolah Sepakbola Emsyk, dalam bentuk edukasi dan pendampingan yang dilakukan secara daring serta luring. Edukasi protokol kesehatan dilakukan dalam bentuk ceramah dan diskusi secara daring untuk memberikan pemahaman seluruh siswa Sekolah Sepakbola Emsyk akan protokol kesehatan olahraga. Pendampingan dilakukan dalam membantu dan memastikan Sekolah Sepakbola Emsyk taat dalam pelaksanaan protokol kesehatan. Hasil dari evaluasi kegiatan yang dilakukan adalah Sekolah Sepakbola Emsyk telah mampu melaksanakan protokol kesehatan olahraga yang sesuai standar internasional, khususnya untuk komunitas sepakbola amatir. Selanjutnya, disarankan agar dilakukan kegiatan serupa, namun menjangkau lingkungan terdekat dari komunitas SSB seperti keluarga dan komunitas penonton.

\section{UCAPAN TERIMA KASIH}

Tim Pengabdian mengucapkan terima kasih kepada Direktur, Pelatih, dan seluruh siswa Sekolah Sepakbola Emsyk, Jayapura atas kesediaan menjadi mitra dalam kegiatan pengabdian ini. Ucapan terima kasih juga diberikan kepada Universitas Cenderawasih, melalui Lembaga Penelitian dan 
Pengabdian kepada Masyarakat, yang telah sepenuhnya mendanai kegiatan pengabdian ini, melalui Hibah PkM PNBP dengan Nomor Kontrak: 143/UN20.2.1/AM/2020.

\section{DAFTAR PUSTAKA}

Abel, T., \& McQueen, D. (2020). The COVID-19 pandemic calls for spatial distancing and social closeness: not for social distancing! International Journal of Public Health, 65(3), 231. https://doi.org/10.1007/s00038-02001366-7

Blocken, B., Malizia, F., Van Druenen, T., \& Marchal, T. (2020). Towards aerodynamically equivalent COVID19 $1.5 \mathrm{~m}$ social distancing for walking and running. Preprint. https://www.euroga.org/system/1/user_files/files/000 /045/111/45111/150d3060c/original/Social_Distancin g_v20_White_Paper.pdf

Fédération Internationale de Football Association. (2020). COVID-19: Medical Considerations for a Return to Footballing https://resources.fifa.com/image/upload/1718covid-19-medical-considerations-for-a-return-tofootballingactivity.pdf? cloudid=cpng0f3y 5 pclmxn0prdb

Hutajulu, P. T., \& Togibasa, O. (2019). Pelatihan dan Pendampingan bagi Pelatih SSB Usia Dini Dalam Melatih Akurasi Tendangan Menggunakan. Jurnal Pengabdian Papua, 3(1), 21-25. http://ejournal.uncen.ac.id/index.php/JP/article/vie $w / 926$

Pranata, D. Y. (2020). Aktivitas Olahraga Masyarakat Pada Masa Pandemi Covid-19 Berdasarkan Usia. Altius: Jurnal Ilmu Olahraga Dan Kesehatan, 9(2), 32-38. https://ejournal.unsri.ac.id/index.php/altius/article/vi $\mathrm{ew} / 12543$

Sekretaris Kabinet Republik Indonesia. (2020). 7 Arahan Presiden Terbary terkait Percepatan Penanganan Covid-19. https://setkab.go.id/7-arahan-presidenterbaru-terkait-percepatan-penanganan-covid-19/

Seto, W. H., Tsang, D., Yung, R. W. H., Ching, T. Y., Ng, T. K.,
Ho, M., Ho, L. M., \& Peiris, J. S. M. (2003). Effectiveness of precautions against droplets and contact in prevention of nosocomial transmission of severe acute respiratory syndrome (SARS). The Lancet, 361 (9368), 1519-1520. https://doi.org/10.1016/S01406736(03)13168-6

Tiksnadi, B., Sylviana, N., Cahyadi, A., \& Undarsa, A. (2020). Routine Exercise to Improve Immunity in Hypertensive Patients During COVID 19 Pandemic. Indonesian Journal of Cardiology, 41(2), 112-119. https://doi.org/10.30701/ijc.1016

Togibasa, O., \& Hutajulu, P. T. (2019). Pengenalan Alat Ukur Digital bagi Sekolah Sepak Bola di Kota Jayapura. Jurnal Pengabdian Papua, 3(2). http://ejournal.uncen.ac.id/index.php/JP/article/vie $w / 934$

Wang, B., Zhang, A., Sun, J. L., Liu, H., Hu, J., \& Xu, L. X. (2005). Study of SARS Transmission Via Liquid Droplets in Air. Journal of Biomechanical Engineering, 127(1), 32-38. https://doi.org/10.1115/1.1835350

World Health Organization. (2020). Rational Use of Personal Protective Equipment for Coronavirus Disease 2019 (COVID-19). https://apps.who.int/iris/handle/10665/331498

Worldometer. (2020). Coronavirus Update (Live). https://www.worldometers.info/coronavirus/

Xie, X., Li, Y., Sun, H., \& Liu, L. (2009). Exhaled droplets due to talking and coughing. Journal of The Royal Society Interface, 6(6), S703-S714 https://doi.org/10.1098/rsif.2009.0388.focus

Yang, S., Lee, G. W. M., Chen, C.-M., Wu, C.-C., \& Yu, K.-P. (2007). The Size and Concentration of Droplets Generated by Coughing in Human Subjects. Journal of Aerosol Medicine, 20(4), 484-494. https://doi.org/10.1089/jam.2007.0610

Zhu, S., Kato, S., \& Yang, J.-H. (2006). Study on transport characteristics of saliva droplets produced by coughing in a calm indoor environment. Building and Environment, $\quad 41(12)$ 1691-1702. https://doi.org/https://doi.org/10.1016/j.buildenv.200 5.06 .024 